https://doi.org/10.31470/2706-7904-2021-16-36-39

\title{
РОБОТА НАД ТЕКСТАМИ ДЛЯ ДОМАШНЬОГО ЧИТАННЯ ЯК ЗАСІБ ФОРМУВАННЯ АНГЛОМОВНОЇ КОМУНІКАТИВНОЇ КОМПЕТЕНЦЇ̈ СТУДЕНТІВ
}

\author{
Work on Home Reading Texts as a Means of Forming English Communicative \\ Competence of Students
}

\author{
Nataliia Borysova \\ Ph.D. in Pedagogy, Associate Professor \\ Hryhorii Skovoroda University in Pereiaslav (Ukraine) \\ natalieborysova@gmail.com \\ https://orcid.org/0000-0003-2902-106X
}

\begin{abstract}
The abstract reveals the problem of working on home reading texts as a means of forming English communicative competence of students. It is noted that the original text is a separate, individual work of speech. It is emphasized that home reading is mandatory for all language learners, which helps to obtain the necessary information. It must be constant and systematic. There are three main approaches to the study of such a text, which are combined into three models: cultural model, language model, personal growth model. It is emphasized that the $2^{\text {nd }}$ language model of studying a literary text is more suitable for studying the work. It is noted that working with a literary text involves its full understanding through clear tasks. Methodologists distinguish three stages of work: pre-textual, textual and post-textual. It is proved that working on texts from home reading is a means of forming students' communicative competence.
\end{abstract}

Key words: communicative competence, home reading texts, original text, a means of forming communicative competence.

\section{Ветуп Introduction}

Знайомство і вивчення оригінальної художньої літератури $є$ обов'язковим під час опанування іноземних мов. Цінність та необхідність домашнього читання вже давно доведена: студенти працюють із «живою» мовою, а не умовно-навчальною, а також у них є можливість висловити свою думку і дати оцінку твору, його ідейному змісту і героям. У процесі роботи над такими англомовними творами у студентів формується комунікативна компетенція. 
Питанням розвитку комунікативної компетенції під час вивчення іноземної мови останнім часом займалися Н. Борисова (Борисова, 2016), Т. Вольфовська (Вольфовська, 2001), О. Ізмайлова (Ізмайлова, 2010), Л. Нагірний (Нагірний, 2012) та інші.

\section{Методи та методики дослідження Methods and Techniques of the Research}

Для досягнення мети, використано такі методи: теоретичні: узагальнення, систематизація, контент-аналіз навчально-методичних матеріалів; моделювання - для визначення сутності та структури іншомовної компетентності, вивчення зарубіжного й українського; розробки структурно-функціональної моделі формування іншомовної компетентності.

\section{Результати \\ Results}

Основне призначення домашнього читання - отримання інформації із оригінальних текстів. Домашнє читання $є$ обов'язковим для всіх, хто вивчає англійську мову, додатковим по відношенню до підручника, постійним читанням із метою отримання необхідної інформації, при умові, що така діяльність є постійною та систематичною і тому для цього, воно повинно бути універсальним. Проте при цьому може виникнути проблема з різним рівнем підготовленості студентів.

У процесі навчання англійській мові читання $є$ одним 3 основних джерел мовної та соціокультурної інформації. Використання художніх творів, окремих текстів для читання дозволяє не тільки перетворити процес вивчення англійської мови в цікаву, захоплюючу справу, але й допомагає студентам ознайомитися із реаліями англомовних країн.

Часом художній текст $є$ складним за своєю граматичною структурою i незрозумілим із культурологічної точки зору i може містити багато невідомої лексики, що ускладнює його розуміння. Однак граматична i культурологічна складність тексту є мотивацією до поглибленого вивчення цього тексту.

Вважаємо за необхідність виділити три основні підходи до вивчення таких текстів, об’єднуючи їх за трьома моделями, зокрема: культурна модель (коли акцент робиться на соціальний, політичний, історичний контекст, приналежність тексту до літературних течій і жанрів; мовна модель (дозволяє підвищити володіння іноземною мовою, разом із тим роблячи підхід до літератури більш компетентним); модель персонального зростання (коли пропонується висловлювати власну думку, виражати ставлення до прочитаного, 
описувати власний досвід). Зауважимо, що для вивчення оригінального твору більше підходить друга мовна модель опрацювання художнього тексту.

Ураховуючи психолінгвістичні особливості студентів та дидактичні передумови із урахуванням соціокультурного, естетичного й емоційного потенціалу тексту, можна використовувати наступні види вправ для розвитку комунікативних навичок:

(а) мовленнєві вправи: бесіда на задану ситуацію, коментування окремих фрагментів тексту, відповіді на запитання;

(б) монологічні та діалогічні вправи: елементи діалогу фронтального характеру, монологічні висловлювання;

(в) обговорення «абстрактних» тем, діалог на інтелектуальні теми;

(г) лексичні і граматичні вправи: висловлювання - доведення, роздум, оцінка; синонімічні заміни.

Оволодіння естетичним, країнознавчим та соціокультурним потенціалом художнього тексту в процесі вилучення художніх деталей та інтерпретації змістової і смислової інформації тексту $\epsilon$ важливою умовою розвитку комунікативної i професійної компетенції студентів. При виконанні вправ некомунікативні вправи, що передбачають формування лексико-граматичних навичок, виконуються як на заняттях, так і вдома в письмовій формі, залежно від рівня підготовки здобувачів. Репродуктивні і продуктивні комунікативні вправи, що спрямовані на розвиток та вдосконалення умінь усного спонтанного мовлення, повинні виконуватись студентами на занятті.

Робота з оригінальним текстом передбачає його повне розуміння за допомогою поставлених до нього чітких завдань. Методисти виділяють три етапи роботи: передтекстовий, текстовий і післятекстовий. Метою передтекстового етапу роботи $\epsilon$ диференціювання мовних одиниць i мовних зразків. На цьому етапі студенти знаходять невідому лексику і визначають їх семантику, при цьому розвивається мовна здогадка, яка сприяє розвитку навичок прогнозування.

На різних етапах можуть бути використані вправи на розпізнавання слова за семантичною ознакою, за формальною ознакою, розрізнення граматичних явищ, автоматизація розпізнавання лексичних одиниць, трансформаційні вправи, вправи на підставляння, прогнозування змісту того, що читається, робота зі словником, перефразування, передача сюжету тексту, складання характеристики персонажів тощо.

3 огляду на те, що в деяких творах є багато авторських неологізмів, можна запропонувати студентам замінити ці поняття на загальновідомі синоніми та попросити проаналізувати наскільки змінився зміст тексту / висловлення, а заодно сприйняття самого твору, як це вплинуло на характер твору. 
Передача сюжету тексту (визначення найбільш значимих подій і / або епізодів у тексті; оцінка значення вказаної події або епізоду для розвитку сюжету). Цей комплекс вправ використовується на післятекстовому етапі. Дуже гарно розвиває комунікативні навички. Додатковим питанням до сюжету на цьому етапі може послугувати питання про роль мови у творі: як, на думку студентів, мовностилістичні засоби вплинули на сприйняття твору тощо.

Складання характеристики персонажів (відповіді на питання до фрагментів тексту, виділення авторських характеристик; постановка питань до фрагментів тексту) також використовується на післятекстовому етапі і (переважно) для практики мовлення. Вправу на виділення авторських характеристик можна ускладнити, попросивши студентів пояснити способи творення цих характеристик та їх приналежність до конкретних мовностилістичних засобів.

\section{Висновки Conclusions}

Отже, робота над текстами 3 домашнього читання $\epsilon$ одним із засобів формування комунікативної компетенції студентів. При роботі з текстом можна запропонувати прокоментувати експресивний ефект вживання письменником певних слів та виразів, роль емоційно-оціночних прикметників та прислівників, засоби творення гумору, іронії тощо. Іншими видами завдань для перевірки розуміння прочитаного можуть бути: відновлення хронології подій, «упізнавання» персонажів за їхнім описом або висловлюваннями, зіставлення персонажів із подіями тощо, що сприятиме розвитку комунікативних навичок у студентів.

\section{Література References}

Борисова, Н.В. (2016). Психолінгвістичні особливості формування комунікативної компетенції професійно-орієнтованого читання у студентів немовних спеціальностей. Psycholinguistics, 19(1), 15-24.

Вольфовська, Т.О. (2001). Комунікативна компетентність людини як одна 3 передумов досягнення життєвої мети. Шлях освіти, 3, 13-16.

Ізмайлова, О.А. (2010). Формування іншомовної комунікативної компетенції як структурного компоненту комунікативної культури студентів мовних ВНЗ. Викладання мов у вищих навчальних закладах освіти, 17, 66-72.

Нагірний, Л. (2021). Особливості формування іншомовної комунікативної компетенції студентів.

URL:

http://www.chnu.edu.ua/res/chnu.edu.ua/period_vudannia/web13/pdf/2012

1/Liubomyr Nahirnyi.pdf 